\title{
Assessment of the Effectiveness of Online Lectures by Bingham University during the Covid-19 Lockdown in Nigeria
}

\author{
Anthony Igyuve, $\mathrm{PhD}^{1}$, Ben Odeba ${ }^{2}$, Daburi Bello Misal ${ }^{3}$ \\ ${ }^{I}$ Department of Mass Communication, Nasarawa State University, Keffi, Nigeria \\ ${ }^{2}$ Directorate of Academic Planning Bingham University, Karu, Nasarawa State, Nigeria \\ ${ }^{3}$ Directorate of Information and Protocol, Bingham University, Karu, Nasarawa State
}

\begin{abstract}
Following the lockdown in Nigeria as a result of COVID-19 pandemic which affected academic activities, Bingham University in order to run an unbroken academic calendar adopted digital technology to deliver lectures to its students. This research assessed the use of digital media communication technology for delivering lectures by Bingham University during the Covid-19 lockdown. Survey research design was used for the study with documentary, questionnaire and interview as the instruments to elicit information from the respondents. Anchored on the Social Presence Theory, Media Richness Theory and the Diffusion of Innovation Theory, the study validates the assumptions of the aforementioned three theories of computer mediated communication (CMC) that digital media technology creates a considerable high level of social presence in a communication encounter, interactivity and the capability of the digital media to cater for every communication need in the $21^{\text {st }}$ century. Further findings show that the use of online lectures was effective and it enabled Bingham University to complete its academic calendar for 2019/2020 academic session notwithstanding the COVID-19 lockdown in Nigeria. Findings further indicate that both staff and students demonstrated positive attitude towards the use of online lectures by the University. The result of the study also established that both staff and students encountered many challenges such as insufficient proficiency and experience in the use of digital technology for teaching and learning, cost of data, poor internet connectivity and poor power supply among others. Based on the findings, it is recommended that both staff and students undergo further training to improve their skills in the use of digital media technology, provision of adequate power supply, internet facilities and a general enabling environment for virtual teaching and learning to thrive.
\end{abstract}

Keywords: Digital Media, Communication, Online Lecture, Covid-19 Lockdown

\section{INTRODUCTION}

$\mathrm{O}$ ver the past few decades, online or virtual teaching and learning has gained prominence in many institutions of learning all over the world (UNESCO, 2020). In Nigeria, the online lecture is becoming popular and adopted by some schools both at the primary, secondary and institutions of higher learning. Its popularity and adoption became more pronounced during the COVID-19 pandemic and subsequent lockdown. Bingham University is one of the universities in Nigeria that adopted the online lecture during the COVID-19 lockdown in Nigeria. The outbreak of the novel coronavirus(nCovid-19) in Wuhan, China towards the end of 2019, frequently referred to as Covid-19 pandemic, has drastically (and dramatically) changed the order of doing things in almost all aspects of life all over the world. One of the drastic changes is increased rate of adoption and application of digital media communication technology for dissemination of information especially for academic activities.

Bingham University one of the private universities in central Nigeria that adopted online platform to engage her students in academic activities during the lockdown in order to complete her academic calendar for 2019/2020 academic year. Notably, Bingham University is adopting virtual learning for the first time, hence the curiosity of these researchers to assess the success or otherwise of the online teaching and learning by the University. According to the World Health Organization (WHO, 2020), over 1.7 billion children are currently out of school following the Covid-19 lockdown order globally. It is amazing what can be accomplished in the $21^{\text {st }}$ century through the use of digital media technology. Information and communication technology (ICT) has made communication easier, cheaper and most convenient for everyone than ever before in the annals of human existence. This study seeks to investigate the effectiveness of the use of online lecture by Bingham University during the COVID-19 lockdown in Nigeria.

In view of the foregoing, the following research questions are raised to guide the study:

\section{Research Questions}

1) What is the level of ICT proficiency of the lecturers in Bingham University?

2) How effective is the use of online lectures by Bingham University during the COVID-19 lockdown in Nigeria?

3) What is the attitude of both lecturers and students towards online teaching and learning by Bingham University during the Covid-19 lockdown in Nigeria? 
4) What are the challenges encountered by both the lecturers and students during the online lectures?

\section{Significance of the Study}

This study seeks to investigate the success or otherwise of the online lecture by Bingham University during the COVID-19 pandemic lockdown in Nigeria. The study is necessary because it would identify the challenges of online and therefore serve as a reference material for other institutions of higher learning that may want to adopt online teaching and learning.

\section{LITERATURE REVIEW}

\section{Digital Media Communication}

Digital media includes any format or device used to convey content using digital signals. Put differently, digital media refers to talking on cell phone, reading internet articles, online lecture delivery, watch YouTube videos and so on. Digital media is digitized content that can be transmitted over the internet or computer networks which include, but not limited to text, audio, video and graphics. In other words, newspapers, magazines, television and radio networks which are presented on a website or blog fall into this category of digital media communication. As the internet grew, majority of digital media are based on translating analogue into digital data and are stored on the internet instead of storing them on papers as was the case previously. This was followed by computer images, audio and video being stored on the internet and till today, the internet continues to grow, (Taylor \& Perry, 2010)

Getting the right message or information to the right people at the right place, time and with instant response in the $21^{\text {st }}$ century cannot be overemphasized. It has enabled communicators to tell their stories in the form that was not possible some decades ago. Reaching your audience with some level of consistency and feedback are some of the qualities which make digital media communication very strong and far reaching all over the world. It has been described as different medium of communication for the same purpose. That is, engaging the different audience or people in different ways; reaching out to customers or clients in different ways. Indeed, digital media technology has pushed communication beyond borders in such a cost-effective and in such an easy way like never before in the history of human existence.

In earlier times, messages were once distributed by one particular source to their audience. The audience gathered their sources through a certain form of distribution, whether it was newspapers, magazines, radio, or television. Publishers had a great source of power over the information distributed and how it was perceived by the public or the recipients. In other words, the audience or recipients of such information have little or no power over such messages or information. However, all that has drastically changed with the rise of computers and most significantly the Internet.

\section{Communication}

The question here is; "What is communication and why is communication a critical aspect of the study?" There is plethora of definitions of communication as there are communication scholars. However, the most common definition of communication is "every act of transmitting information from one point (source, sender) to (through a channel or medium) another (recipient, audience)". From the broadest perspective, information includes emotions, ideas, thoughts and so on. Communication can take various forms and it has been described as the hub of human existence, be it at societal, institutional, group, interpersonal and or intrapersonal levels. In other words, all human activities revolve around communication. No man can exist without communication, hence the popular slogan in communication palace states that "...you cannot not communicate"; which means that communication is not just the verbal expression of ideas or feelings only.

Igyuve, Odeba and Akpede (2020) describe communication as "the epicenter of human existence". This presupposes that the creation of man and all activities of human life are guided by communication. Although there are specialists who are trained in the science and art of communication, everyone living and in all fields of human endeavour communicates. Therefore, it will be safe to state that communication is the life wire of everyone irrespective of the socio-economic, political or the educational status of the person.

\section{COVID-19 Pandemic}

The Covid-19 pandemic is an ongoing global health concern. According to WHO (2020) the COVID-19 pandemic which is also called coronavirus pandemic is caused by severe acute respiratory syndrome coronavirus 2 (SARS-CoV-2). The outburst was first discovered in Wuhan, China, in December 2019. The World Health Organization (WHO) declared the outbreak a Public Health Emergency of International Concern on January 30 and on March 11, 2020. The virus is primarily spread between people during close contact, most often via small droplets produced by coughing, sneezing, and talking, (WHO, 2020). Schools, universities and colleges have been closed in 172 countries which has affected over 98 percent of the world's student population.

Murphy and Stewart (2015) carried out a study in the United States of America (University of Arkansas and West Virginia University respectively) on "The Impact of Online or F2F Lecture Choice on Student Achievement and Engagement in a Large Lecture-Based Science Course: Closing the Gap". The study is a varied blended learning options and the universities explored an assortment of instructional combinations which involved video lectures as well as face-to-face (f2f) lectures. The findings of the study reveal that the type of lecture does not serve to significantly impact on the overall student achievement of engagement. The reviewed study was done in United States of America while the current one is done in Nigeria. In the study by Murphy and Stewart (2015), the 
students have options to either attend lectures live in the traditional f2f setting or watch recorded video lectures delivered over the internet and or both, but the system adopted in Bingham University has no f2f option for the students. The only option available for Bingham University is a comprehensive deployment of digital media communication for online lectures, continuous assessments (CAs) and examinations.

\section{THEORETICAL FRAMEWORK}

\section{The Social Presence Theory (SPT)}

Social interactions and relationships building and maintenance are integral parts of computer mediated communication (CMC). This new style of relational communication helps individuals and organizations to create a sense of belonging $\mathrm{w}$ ith their stakeholders and at the sametime constantly keeping in touch. Asemah, Gujbawu, Ek hareafo and Okpanachi (2017, p. 266) note that:

"there is a level of connection between individuals, including dialogues and group conversations by having verbal communication or information exchange through the use of a computer network or a computer conferencing system. It is a communication that takes place in the internet domain in which people do not have an opportunity to be with each other physically and spatially, although they share a common space".

Short, Williams and Christie (1976) developed social presence theory which evaluates communication media based on the level of consciousness of the other person's presence in a communication interface. The perception is that some communication media have higher degree of social presence than others. According to Asemah, et al (2017, p. 267), the main assumption of social presence theory is that "in any interaction involving two parties, both parties are concerned with acting out certain roles and with developing or maintaining some sort of personal relationship". It implies that the interactive nature of the media of mass communication made possible through computer mediated communication enables users to share experiences, information and ideas without having to be physically present in the same place of the communication encounter.

\section{Media Richness Theory (MRT)}

Bridging the gap between one-on-one or interpersonal communication and computer mediated communication (CMC) is the main assumption or idea behind the Media Richness Theory (MRT). Web 2.0 has the capacity to create a significant high level of social presence through the use of 'video chatting' and 'teleconferencing'. Draft and Lengel (1990) reviewed the Media Richness Theory to align with the digital world hence, the theory also applies to educational institutions to communicate between teachers and students as well as the larger audience.

Barrow (2009) narrows it down as follows:
Media Richness Theory proposed by Draft and Lengel in 1984 essentially states that task performance increases when the task needs are matched to the medium's richness. In other words, if I use the medium with a richness level most accurately suited to a given task to communicate that information about the task to an individual, the individual's performance of that task will improve.

The view of Barrow (2009) is described here as being the summary of Media Richness Theory because it takes into cognizance, the speed of transmission of information or message, feedback, interactivity, completeness and clarity of message enabled by the richness of the media of communication used.

\section{Diffusion of Innovation Theory (DIT)}

This theory has four (4) main elements which include innovation, communication channels, time and social system. The effectiveness of diffusion of innovation centers on availability and accessibility of digital media technology at the micro and macro social systems. Diffusion of Innovation Theory was developed by Everest Rogers (1962). The adoption of the innovation suggests that the micro and macro social systems begin to do something differently (Asemah, Nwammuo and Nkwam-Uwaoma, 2017). (Ayodele, 2012).

\section{Research Methodology}

Survey design was used for the study. This is because of the need to study a fairly large population. Furthermore, survey research technique is an in-depth project that seeks to unravel why people differ in their opinions, views and perceptions of events and issues. The choice of survey design is also informed by the assertion that survey design is appropriate for investigating problems in a realistic environments and settings and that its cost is reasonable considering the huge amount of information or data it can be employed to generate. It also facilitates analysis of data; allows for immediate feedback, enables mass communication researchers to measure characteristics and behaviours of the population (Baran, 2010).

Documentary, questionnaire and interviews were used for data collection. The online interview and discussions were used for students and lecturers who could not be reached physically because of the COVID-19 lockdown. The study used both published and unpublished secondary sources of information such as textbooks, journals, magazines, newspapers, bulletins and internet materials for the study. These instruments were adopted because of the peculiarity of the period of time within which the study was carried out.

\section{DATA PRESENTATION AND ANALYSIS}

\section{Results}

The 214 administered copies of questionnaire were collated and analyzed. There was a response and return rate of $97 \%$ as 5 copies were not returned and 2 were incompletely filled. 
The results presented below are based on the 207 copies of the questionnaire that were properly completed and returned.

Table 1: Respondents Level of ICT Proficiency

Table 1: ICT Proficiency of Respondents

\begin{tabular}{|c|c|c|}
\hline Variables & Frequency & Percentage (\%) \\
\hline Advanced skills \\
\hline Yes & 93 & $45 \%$ \\
\hline No & 114 & $55 \%$ \\
\hline Total & 207 & $100 \%$ \\
\hline Intermediate skills & 112 & $54 \%$ \\
\hline Yes & 95 & $46 \%$ \\
\hline No & 207 & $100 \%$ \\
\hline Total & & \\
\hline Elementary skills & 134 & $65 \%$ \\
\hline Yes & 73 & $35 \%$ \\
\hline No & 207 & $100 \%$ \\
\hline Total & & \\
\hline
\end{tabular}

Source: Field Survey, 2020

The analysis in Table 1 shows the level of ICT proficiency of the respondents. 93 respondents representing $45 \%$ said they have acquired advanced skills in the use of information and communication technology (ICT) while 114 respondents representing 55\% said they do not have advanced skills in computer proficiency. This means less than half of the respondents that is, $45 \%$ have developed their computer proficiency to the advanced stage. In other words, quite a large number of the respondents (114) which represents 55\% of the respondents are yet to develop their ICT skills above average or intermediate level.

Respondents with intermediate level of ICT proficiency are 112 representing 54\% while respondents whose ICT proficiency is below the intermediate level are 95 representing $46 \%$. 134 respondents representing $65 \%$ have acquired only the elementary level of computer skills, which means that most of the respondents are not adequately skillful in the use of digital technology for teaching and learning as at the time of this study,

Table 2: Online Lecture Experience of the Lecturers in Bingham University

\begin{tabular}{|c|c|c|}
\hline Variables & Frequency & Percentage \\
\hline Yes & 125 & $60 \%$ \\
\hline No & 82 & $40 \%$ \\
\hline Total & 207 & $100 \%$ \\
\hline
\end{tabular}

Source: Field Survey, 2020

One hundred and twenty-five (125) respondents representing $60 \%$ said they had experience in the use of online lecture for content delivery while 82 respondents which represents $40 \%$ said they did not have experience in the use of digital media for teaching. This means that a great number of lecturers in
Bingham University have experience in the use of online lecture. Forty percentage of the lecturers never engaged students in online lectures before the Bingham University experience.

Table 3: Level of participation in the online teaching and learning by Bingham University Lecturers and Students

Level of Respondents' Participation in the Online Lecture

\begin{tabular}{|c|c|c|}
\hline Variables & Frequency & Percentage (\%) \\
\hline \multicolumn{3}{|l|}{$10-60 \%$} \\
\hline Strongly agree (SA) & 9 & $4 \%$ \\
\hline Agree (A) & $700 \%$ & $3 \%$ \\
\hline \multicolumn{3}{|l|}{ Undecided (U) } \\
\hline \multicolumn{3}{|l|}{ Disagree (D) } \\
\hline \multicolumn{3}{|l|}{ Strongly Disagree (SD) } \\
\hline Total & 16 & $7 \%$ \\
\hline \multicolumn{3}{|l|}{$61-80 \%$} \\
\hline Strongly agree (SA) & 8 & $4 \%$ \\
\hline Agree (A) & 4 & $2 \%$ \\
\hline \multicolumn{3}{|l|}{ Undecided (U) } \\
\hline \multicolumn{3}{|l|}{ Disagree (D) } \\
\hline \multicolumn{3}{|l|}{ Strongly Disagree } \\
\hline Total & $1200 \%$ & $6 \%$ \\
\hline \multicolumn{3}{|l|}{$81-100 \%$} \\
\hline Strongly agree (SA) & 91 & $44 \%$ \\
\hline Agree (A) & 88 & $43 \%$ \\
\hline Undecided (U) & - & - \\
\hline Disagree (D) & - & - \\
\hline \multicolumn{3}{|l|}{ Strongly Disagree } \\
\hline Total & 207 & $100 \%$ \\
\hline
\end{tabular}

Source: Field Survey, 2020

Table 3 gives the analysis of the level of respondents' participation in the online teaching and learning by Bingham University. The result of the analysis shows that 16 (9 strongly agree and 7 agree) respondents representing $7 \%$ said the $10-60 \%$ participated in the online lectures; while 12 respondents (8 strongly agree and 4 agree) respectively state that $61-80 \%$ of the respondents took part in the online lectures. Furthermore, 91 and 88 (179) respondents representing $44 \%$ and $43 \%$ (87\%) respectively strongly agree and agree that the average number of participants in the online lectures is between $81-100 \%$. This shows a high level of participation in the online lectures adopted by Bingham University.

Table 4: Respondents rating of the online lectures by Bingham University

\begin{tabular}{|c|c|c|}
\hline Variables & Frequency & Percentage (\%) \\
\hline Very effective & & \\
\hline Strongly agree (SA) & 67 & $32 \%$ \\
\hline
\end{tabular}




\begin{tabular}{|c|c|c|}
\hline Agree (A) & 102 & $49 \%$ \\
\hline Undecided (U) & - & - \\
\hline Disagree (D) & - & - \\
\hline Strongly Disagree (SD) & - & $81 \%$ \\
\hline Total & 169 & \\
\hline & & $12.30 \%$ \\
\hline Effective & & $6.70 \%$ \\
\hline Strongly agree (SA) & 25 & - \\
\hline Agree (A) & 13 & - \\
\hline Undecided (U) & - & $19 \%$ \\
\hline Disagree (D) & - & $100 \%$ \\
\hline Strongly Disagree (SD) & - & - \\
\hline Total & & - \\
\hline Not Effective & & - \\
\hline Strongly agree (SA) & - & - \\
\hline Agree (A) & - & - \\
\hline Undecided (U) & - & - \\
\hline Disagree (D) & - & - \\
\hline Strongly Disagree (SD) & - & - \\
\hline Total & & \\
\hline
\end{tabular}

\begin{tabular}{|c|c|c|}
\hline Strongly Disagree & - & $100 \%$ \\
\hline Total & 207 & \\
\hline Negative attitude & & - \\
\hline Strongly agree (SA) & - & - \\
\hline Agree (A) & - & - \\
\hline Undecided (U) & - & - \\
\hline Disagree (D) & - & - \\
\hline Strongly Disagree & - & - \\
\hline Total & - & - \\
\hline
\end{tabular}

Source: Field Survey, 2020

Data analysis in table 5 shows the attitude of the respondents towards the online lecture adopted by Bingham University during the COVID-19 pandemic lockdown in Nigeria. 124 respondents representing $60 \%$ strongly agree that the respondents showed a positive attitude towards the online lecture while 83 respondents representing $40 \%$ agree that the respondents showed positive attitude towards the online lecture by Bingham University. In other words, no respondent showed any negative attitude towards the exercise.

Table 6: Respondents rating of the social presence created by digital media technology

\begin{tabular}{|c|c|c|}
\hline Variables & Frequency & Percentage (\%) \\
\hline $\begin{array}{c}\text { Very high level of social } \\
\text { presence }\end{array}$ & & \\
\hline Strongly agree (SA) & 92 & $44 \%$ \\
\hline Agree (A) & 104 & $50 \%$ \\
\hline Undecided (U) & - & \\
\hline Disagree (D) & 11 & $6 \%$ \\
\hline Strongly Disagree & - & \\
\hline Total & 207 & $100 \%$ \\
\hline High level of social presence & & \\
\hline Strongly agree (SA) & 107 & $52 \%$ \\
\hline Agree (A) & 100 & $48 \%$ \\
\hline Undecided (U) & - & - \\
\hline Disagree (D) & - & - \\
\hline Strongly Disagree & - & - \\
\hline Total & 207 & $100 \%$ \\
\hline
\end{tabular}

Source: Field Survey, 2020

Data in table 6 shows the perception of the respondents on the social presence created by digital media technology in a communication encounter during the online lecture by Bingham University. The analysis shows that 92 respondents representing $44 \%$ strongly agree that digital media technology creates a very high level of social presence in an interactive communication while 104 respondents representing 50\% agree that digital media technology creates a very high level of social presence in a dialogic communication. On this same rating, 11 respondents which represents $6 \%$ disagree that the 
social media technology does not create a very high level of social presence in a relational dialogic communication.

The data analysis in table 6 further shows that 107 respondents representing 52\% strongly agree that social media technology creates a high level of social presence in an interactive communication while 100 respondents which represents $48 \%$ agree that digital media technology creates a high level of social presence in a dialogic or two-way communication.

In other words, $94 \%$ (that is, $44 \%+50 \%$ strongly agree and agree respectively) rate the social presence created by digital media technology as "very high level of social presence". Only 6\% of the respondents disagree with this rating. Considering the high percentage of the respondents who strongly agree and agree that digital media technology creates a very high level of social presence in a two-way communication, it is safe to assert that there is a very high level of social presence being created by using digital media technology for interactive communication. Similarly, 100\% of the respondents also strongly agree $(52 \%)$ and agree $(48 \%)$ that digital media technology creates a high level of social presence in a dialogic communication encounter.

Table 7: Respondents preferred mode of teaching and learning

\begin{tabular}{|c|c|c|}
\hline Variables & Frequency & Percentage $(\%)$ \\
\hline \multicolumn{3}{|c|}{$\begin{array}{c}\text { Online or Virtual Teaching and } \\
\text { Learning }\end{array}$} \\
\hline Strongly agree (SA) & 92 & $44 \%$ \\
\hline Agree (A) & 95 & $46 \%$ \\
\hline Undecided (U) & - & \\
\hline Disagree (D) & 11 & $6 \%$ \\
\hline Strongly Disagree & 9 & $4 \%$ \\
\hline Total & 207 & $100 \%$ \\
\hline \multicolumn{3}{|c|}{$\begin{array}{c}\text { Face-to-face (f2f) Teaching and } \\
\text { Leaning }\end{array}$} \\
\hline Strongly agree (SA) & 102 & $49 \%$ \\
\hline Agree (A) & 105 & $51 \%$ \\
\hline Undecided (U) & - & \\
\hline Disagree (D) & - & \\
\hline Strongly Disagree & - & \\
\hline Total & 207 & $100 \%$ \\
\hline \multicolumn{3}{|c|}{$\begin{array}{c}\text { Combined (f2f \& online) Modes of } \\
\text { Teaching and Leaning }\end{array}$} \\
\hline Strongly agree (SA) & 116 & $56 \%$ \\
\hline Agree (A) & 91 & $44 \%$ \\
\hline Undecided (U) & - & - \\
\hline Disagree (D) & - & - \\
\hline Strongly Disagree & - & - \\
\hline Total & 207 & $100 \%$ \\
\hline
\end{tabular}

Source: Field Survey, 2020
The analysis in Table 7 shows the respondents' preferred mode of teaching and learning. the first part of the table shows that 92 respondents representing $44 \%$ and 95 respondents representing $46 \%$ strongly agree and agree respectively that they prefer Online or Virtual Teaching and Learning. 11 respondents representing 6\% disagree while 9 respondents representing 4\% strongly disagree with this preference. The analysis in the second section of Table 7 shows that 102 respondents representing 49\% strongly agree or preferred the face-to-face (f2f) mode of teaching and learning while 105 respondents representing $51 \%$ agree that they prefer face-to-face teaching and learning. The third and last segment of Table 7 shows that 116 respondents representing 56\% strongly agree that the combined modes, that is, $\mathrm{f} 2 \mathrm{f}$ and online modes of teaching and learning are most preferred while 91 respondents representing $44 \%$ agree that the combined modes of teaching and learning are preferrable. In other words, face-to-face and online modes of teaching and learning are most preferrable. It is therefore safe to state that the respondents prefer the combined modes of teaching and learning to all the other modes of teaching and learning.

Table 8: Both Staff and Students encountered challenges in using the online lectures adopted by Bingham University during the Covid-19 lockdown in Nigeria.

\begin{tabular}{|c|c|c|}
\hline Variables & Frequency & Percentage (\%) \\
\hline Strongly agree (SA) & 135 & $65 \%$ \\
\hline Agree (A) & 72 & $35 \%$ \\
\hline Undecided (U) & - & \\
\hline Disagree (D) & - & \\
\hline Strongly Disagree & - & \\
\hline Total & 207 & $100 \%$ \\
\hline
\end{tabular}

Source: Field Survey, 2020

In table 8, the analysis shows that 135 respondents representing $65 \%$ strongly agree that staff and students encountered challenges while 72 respondents representing $35 \%$ agree that both staff and students encountered some challenges during the online lectures adopted by Bingham University.

Table 9: The Respondents' perceived challenges encountered by both staff and students in the online lectures adopted by Bingham University include; lack of internet connectivity, epileptic power supply, inability to demonstrate complex theories and models, lack of or poor interactivity in the platform deployed, difficulty in generating and uploading contents, etc.

\begin{tabular}{|c|c|c|}
\hline Variables & Frequency & Percentage (\%) \\
\hline Strongly agree (SA) & 145 & $70 \%$ \\
\hline Agree (A) & 62 & $30 \%$ \\
\hline Undecided (U) & - & \\
\hline Disagree (D) & - & \\
\hline Strongly Disagree & - & \\
\hline Total & 207 & $100 \%$ \\
\hline
\end{tabular}

Source: Field Survey, 2020 
The analysis in table 9 shows that 145 respondents representing $70 \%$ strongly agree that both staff and students encountered some challenges such as lack of internet connectivity, epileptic power supply, inability to demonstrate complex theories and models, lack of or poor interactivity in the platform deployed, difficulty in generating and uploading contents, etc. during the online lectures which Bingham University adopted while 62 respondents representing 30\% agree that both staff and students encountered same challenges.

\section{Answering the Research Questions}

The first research is "In what ways has the use of digital media communication helped Bingham University to carry out academic activities for the second semester of 2019/2020 academic session? In answering this question, the researchers relied on the responses from both the questionnaire, interviews and group discussions conducted to elicit data from respondents. Responses show that all staff and students of Bingham University participated in the online lectures, quizzes, assignments and examinations. This shows that overwhelming majority of the students took part in the exercise.

The research question two is "How has the use of digital media communication technology affected the attitude of both lecturers and students towards teaching and learning during the Covid-19 lockdown in Nigeria?" The responses of the respondents show that virtual learning positively affected the attitude of both lecturers and students. The students' lecture attendance is over $90 \%$ while $95 \%$ participated in the online examinations. The responses here also show that $40 \%$ of the students participated in virtual learning and assessment for the first time while $60 \%$ of lecturers are using the internet for teaching for the first time. This suggests that both teachers and students need more training on the use of virtual teaching and learning.

The third research question for the study is "What are the challenges encountered by both the lecturers and students during the online lectures?" In responding to this question, both lecturers and students encountered a plethora of challenges which include unreliable internet connectivity, extra cost incurred on data, lack of interactions and inability to demonstrate some important concepts, principles, theories and inability to show detailed steps involved in solving problems with examples.

\section{DISCUSSION}

The study examined the use of online lectures by Bingham University during the COVID-19 lockdown in Nigeria to determine the effectiveness or otherwise of the online teaching and learning. The study further sought to identify the challenges encountered by both students and lecturers in the online lecture adopted by the University for the second semester of the 2019/2020 academic session.

Quite a number of challenges were encountered which include; unreliable internet connectivity extra cost incurred on data subscription by both lecturers and students, limited interactivity and low level of social presence, inability to demonstrate some important concepts, principles and to show detailed steps involved in solving problems as well as examples by the lecturers. Bingham University staff and students have been used to face to face (f2f) mode of teaching and learning where the communicator (lecturer) and the audience (students) are physically present in a communication encounter or engagement during lectures. The findings show that f2f form of communication has the highest level of social presence whereby the facial expression or body language of the communicator enhances the understanding of the communication and provides opportunity for the recipients to facially respond to the information received. This is in line with the main assumption of the social presence theory developed by Short, Williams and Christie (1976); the basic tenet of social presence theory is that it evaluates communication media based on the level of consciousness of the other person's presence in a communication interface. The differences play a vital role in how people interact with one another and the effectiveness of the interaction.

The findings of the study show that more than $90 \%$ of the respondents prefer face-to-face form of communication which creates the highest level of social presence and enables lecturers to demonstrate and explain complex theories and models. Over $80 \%$ of the respondents are of the view that face-to-face and digital modes of lecture delivery should be combined. Nevertheless, the adoption of online lecture enabled Bingham University to complete her academic calendar for 2019/2020 academic session despite the COVID19 lockdown in Nigeria. These findings validate both the theories of the study and the position of Murphy and Stewart (2015)

\section{CONCLUSION AND RECOMMENDATION}

The study concludes that inspite of the many challenges encountered, the online lecture by Bingham University was successful. Bingham University prides itself as one of the leading prestigious privately funded universities in Nigeria. There is a general enthusiasm among both the lecturers and students for the initiative and innovation by the University Management. Although more than $90 \%$ of the participants are aware of the existence of online or virtual teaching and learning, more than $70 \%$ of them never participated in online teaching and learning before the Bingham University experience. More than $60 \%$ of the respondents lacked the required ICT knowledge and proficiency for this new approach to teaching and learning. The result indicates that most $(80 \%)$ of the respondents demonstrated positive attitude towards the use of online lectures while more than $80 \%$ of the respondents affirmed that the online lecture was effective.

Based on the findings and the conclusion, the study recommends among others that a combination of online and face-to-face modes of teaching and learning should be encouraged and adopted. 


\section{REFERENCES}

[1] Asemah, E. S., Nwammuo, A. N. and Nkwam-Uwaoma, A. O. (2017). Theories and Models of Communication. Jos: University Press.

[2] Baran S. J. (2010). Introduction to Communication, Media Literacy and Culture. McGraw-Hill publication.

[3] Barrow, T. (2009). Media Richness Theory. Available at: http://blog.timebarrow.com/2009/09/media-richness-theory/. Assessed 5/5/2020. Igyuve, A. I.. Odeba, B. I. and Akpede, K. S. (2020). Strategic Communication for Managerial Efficiency. International Journal of Commerce and Management Research, 6(1), 11-15.

[4] Kaplan, A. M. \& Haenlein, M. (2013). Users of the world, unite! the challenges and opportunities of social media. Business Horizons, 53 (1), 59-68.
[5] John Hopkins University (JHU) (2020). COVID-19 Dashboard by the Center for Systems Science and Engineering (SSE). ArcGIS. Johns Hopkins University. Retrieved 2 July 2020.

[6] Jenkins, H. (2006). Convergence Culture: Where Old and New Media Collide. New York: New York University Press.

[7] Murphy, and Stewart (2015). The Impact of Online or f2f Lecture Choice on Student Achievement and Engagement in a Large Lecture-Based Science Course: "Closing the Gap".

[8] Taylor, M, \& Perry D.C. (2010). "Diffusion of Traditional and New Media Tactics in Crisis Communication". Public Relations Review, 3 (2): 209217.

[9] WHO (2020). "Naming the Coronavirus Disease (COVID-19) and the Virus that Causes it". World Health Organization (WHO). Retrieved 23 April 2020

[10] WHO (2020). "Coronavirus very likely of Animal Origin, no sign of Lab Manipulation: WHO". Reuters. 21 April 2020. Retrieved 23 April 2020. 